\title{
Testicular Trauma Injury Scale
}

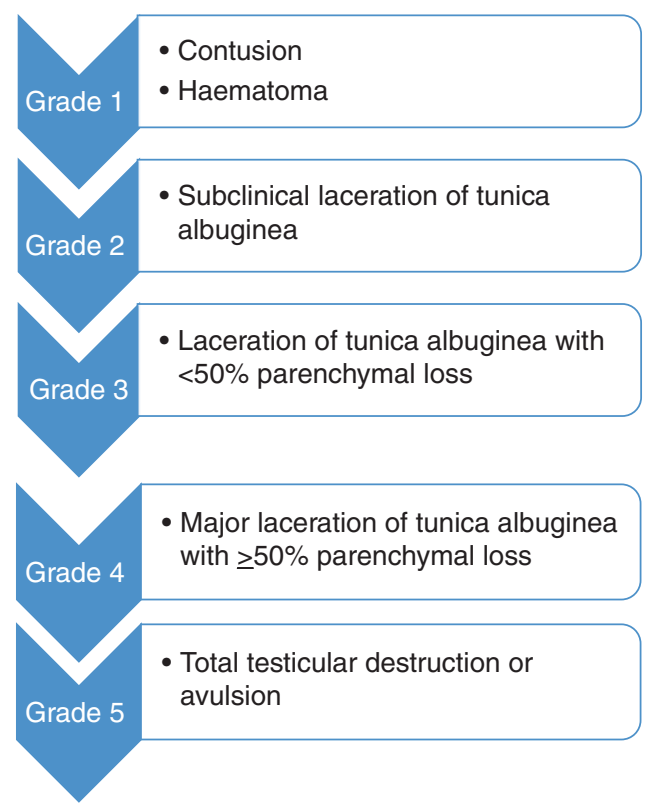

\section{Suggested Reading}

1. Morey AF, Brandes S, Dugi DD III, Armstrong JH, Breyer BN, Broghammer JA, Erickson BA, Holzbeierlein J, Hudak SJ, Mirvis S, Pruitt JH, Reston JT, Santucci RA, Smith TG III, Wessells H. Urotrauma: AUA guideline. J Urol. 2014;192(2):327-35. 